\title{
Effects of processing on nutritional composition and quality evaluation of candied celeriac
}

\author{
GRETA KREŠIĆ ${ }^{a, *}$, VESNA LELAS ${ }^{b}$ and BORISLAV ŠIMUNDIĆ $a$ \\ ${ }^{a}$ Faculty of Tourism and Hospitality Management, Department of Nutrition, \\ University of Rijeka, Naselje Ika, Primorska 42, p.p.97, 51410 Opatija, Croatia \\ ${ }^{b}$ Faculty of Food Technology and Biotechnology, University of Zagreb, \\ Pierrottijeva 6, HR-10000 Zagreb, Croatia \\ e-mail: Greta.Kresic@hika.hr
}

MS received 3 June 2003; revised 28 August 2003

\begin{abstract}
In this work, a new candying procedure with partial re-use of sugar syrup is proposed. Physicochemical analysis, together with sensory evaluation, of candied celeriac samples was done. Candying was performed in a pilot unit at $65^{\circ} \mathrm{C}$, through three cycles of 5 hours duration each. Sugar syrups of $75^{\circ}$ Brix were used. Effects of $1 \%(\mathrm{~m} / \mathrm{v})$ citric and $1 \%(\mathrm{~m} / \mathrm{v})$ ascorbic acid addition, as well as the drying of candied celeriac $\left(60^{\circ} \mathrm{C}\right.$ for $\left.8 \mathrm{~h}\right)$ were studied. Sugar syrup deterioration was estimated by the concentration of hydroxymethylfurfural. The results obtained showed that there were no significant $(P<0.01)$ differences in total dry matter and total sugar content between samples, while the increases after drying were significant $(P>0 \cdot 01)$. Differences were observed in sugar compositions between samples. After three cycles, samples turned lighter, with decreased $L^{*}$ values after drying. The celeriac from the first cycle of the ascorbic acid addition procedure was adjudged best with respect to all quality parameters. The decreased concentration of hydroxymethylfurfural confirmed that re-use of sugar syrup is possible.
\end{abstract}

Keywords. Ascorbic acid; candying; colour; hydroxymethylfurfural; sensory evaluation; sugar syrup.

\section{Introduction}

Celery (Apium graveolens L.) from the family Apiacea is cultivated in three forms: var. rapaceum (Mill.), var. dulce (Mill.) and var. secalinum (Alef). Var. rapaceum is the most cultivated form, characterised by white colour inside and yellow to brown outside the edible tuber (celeriac) (Hermann 1996).

According to food composition data, celery tuber has $11.4 \%$ total dry matter content and contains about $0.94 \%$ minerals, of which potassium is present in notable amounts (about 414 $\mathrm{mg} 100 \mathrm{~g}^{-1}$ ). Celeriac also contains $\approx 1.55 \%$ of proteins, $0.33 \%$ fat, $2.25 \%$ of total sugars

*For correspondence 
and $4.23 \%$ total dietary fibre (Souci et al 2000). In celery tubers, the presence of vitamin K $\left(100 \mathrm{mg} 100 \mathrm{~g}^{-1}\right.$ ) is also detected, as well as vitamin C ranging from $6.0 \mathrm{mg} 100 \mathrm{~g}^{-1}$ (Kulier

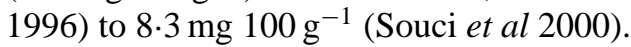

Beside the minerals, vitamins and dietary fibre content, celery is in use because of its characteristic aroma and health benefits which include positive effects on lipid levels (Tsi $\&$ Tan 2000) and the potential anticarcinogenic properties (Hertog et al 1992; Crozier et al 1997).

Usually, celery is processed by drying, but investigations have been carried out also on the other kinds of products such as juices (Hicks et al 1996), fresh salads (Nicholl \& Predergast 1998) and frozen purees (Torres \& Canet 2001).

The candying process involves the slow impregnation of syrup, until the sugar concentration in the tissue is sufficiently high to prevent the growth of spoilage microorganisms (Desrosier $\&$ Desrosier 1977). Candied products contain 65-70\% sugar with water activity values of 0.6-0.8 which predict long shelf life with no microbial growth (Chen 1989). During treatment with sugar solution, a removal of the natural water content in fruits or vegetables occurs while the sugar solution diffuses into the food (Giangiacomo et al 1987; Rastogi \& Nirinjan 1998). Mostly, investigations have been carried out with fruits candied in processes where sugar solution increases by $10^{\circ}$ Brix daily (Chen 1989; Mohamed et al 1993). Since some studies (Ballerini-Goffe 1992; Enze 1994; Kowalska \& Lenart 2001; Rahman et al 2001) have proposed sugar syrup utilization to produce vegetable ingredients (potato, carrot, asparagus, ginseng, pumpkin) with reduced water activity in this paper we present a new commercially unknown use for celery tuber.

Therefore, the main objectives of this work are: (1) to investigate if candying procedures with three cycles of 5 hours duration each, could ensure acceptable candied products; (2) to compare the influence of ascorbic and/or citric acid addition in the first cycle on the nutritive composition, sensory evaluation and colour of twelve candied products; (3) to determine if candying procedures cause browing and deterioration of sugar syrups; (4) to investigate if drying causes significant changes in candied products.

\section{Materials and methods}

\subsection{Candied celeriac preparation}

Celeriac (Apium graveolens var. rapaceum (Mill.) DC) used in this research was selected at random from the fresh fruit and vegetable section of a local supermarket (Zagreb, Croatia). Celery tubers that were not processed immediately were kept wrapped in polyethylene bags and stored at room temperature for not more than $48 \mathrm{~h}$.

After sorting, washing and peeling, the celeriac was cut into cubes (10 $\mathrm{mm}$ each side) and pre-treated with boiling water until optimal softness for candying was reached. Preliminary screenings were carried out to ascertain the pre-treatment duration (Krešić et al 2002). Four different candying procedures (C, CD, CA, CAD) of three cycles each were carried out. Procedures differed according to composition of initial sugar syrup used in the first cycle (discussed below) and whether or not drying procedures were carried out. Three cycles were carried out to investigate the possibility of saving sugar. In each procedure, samples were marked as 1,2 and 3. These notations represented the candying cycle that the samples were from. Candied celeriac were marked as C1-C3 and CA1$\mathrm{CA} 3$, respectively. Candied dried celeriac were marked as CD1-CD3 and CAD1-CAD3 respectively. 
After pretreatment celeriac cubes were steeped in initial sugar syrup. The sugar syrups used in the first cycle were as follows:

Procedures C and CD: $20^{\circ}$ Brix containing $1 \%(\mathrm{~m} / \mathrm{v})$ citric acid.

Procedures CA and CAD: $20^{\circ}$ Brix containing $1 \%(\mathrm{~m} / \mathrm{v})$ citric acid and $1 \%(\mathrm{~m} / \mathrm{v})$ ascorbic acid.

Candying was done by increasing the steeping syrup concentration to $40^{\circ}$ Brix after the first hour, then to $55^{\circ}$ Brix after the second hour and by $10^{\circ}$ Brix hour $^{-1}$ to reach $75^{\circ}$ Brix finally. In $75^{\circ}$ Brix solution cubes were steeped for 1 hour. Every hour, after the refractometric index was measured, commercial food grade sucrose was manually added to increase the total dry matter. The mass ratio of solid to solution was 1:4, for economic reasons and to ensure the quality of final product. Maintaining this ratio we could ensure even steeping of the cubes in sugar solution. Five hundred grams of celeriac cubes per batch were candied in a pilot unit at $65^{\circ} \mathrm{C}$. At the end of the first cycle, the remaining sugar solution was diluted with water for obtaining $20^{\circ}$ Brix solution, which was then used as an initial sugar syrup for the second cycle. Pretreated celeriac cubes were added to the prepared sugar syrup, and candying was done as previously described. The same procedure was repeated in the third cycle. After candying the celeriac cubes the solution was drained out. Half of the samples from procedures $\mathrm{C} 1$, C2 and C3 were finally dried in a laboratory cabinet air dryer constructed at the Faculty of Food Technology and Biotechnology, University of Zagreb (samples marked as: CD1, CD2 and CD3). In the same way, equal amounts of samples from procedures CA1, CA2, and CA3 were also dried (samples marked as CAD1, CAD2 and CAD3). The dimensions of the drying chamber were: length $0.2 \mathrm{~m}$, height $0.37 \mathrm{~m}$ and width $0.2 \mathrm{~m}$. Candied celeriac cubes were spread on the chamber's three wire mesh trays (dimensions $0.19 \mathrm{~m} \times 0.3 \mathrm{~m} \times 0.15 \mathrm{~m}$ ) and conventionally air dried with cross flow air at $60^{\circ} \mathrm{C}$ for $8 \mathrm{~h}$. The optimal drying conditions for this type of products were previously described by Mohamed et al (1993). The browning of sugar syrups as a measure of deterioration was evaluated by hydroxymethylfurfural (HMF) concentration measurements.

\subsection{Physicochemical analyses}

The total dry matter content (\%) was determined by drying at $105^{\circ} \mathrm{C}$ to constant weight, in accordance with AOAC (1980).

The refractometric index $\left({ }^{\circ}\right.$ Brix $)$ of the sugar syrups was measured with a refractometer (Model AT 810, Mom Gyem, Budapest, Hungary).

The $\mathrm{pH}$ of the extract, obtained after mixing of $20 \mathrm{~g}$ sample in $100 \mathrm{~mL}$ of distilled water and filtering, was measured using a glass electrode laboratory pH-meter (Model MA 5740, Iskra, Kranj, Slovenia). An average of four readings per sample procedure was adopted.

Total acidity was determined by potentiometric titration. Twenty-five grams of sample were homogenized in a blender and diluted with distilled water to $250 \mathrm{~cm}^{3}$ in a volumetric flask. After homogenization, samples were cooked for 30 minutes in a water bath and then diluted to $250 \mathrm{~cm}^{3}$. Finally, the solution was filtered through filter paper, and $25 \mathrm{~cm}^{3}$ of filtrate was titrated with $0 \cdot 1 \mathrm{M} \mathrm{NaOH}$ to $\mathrm{pH} 8 \cdot 1$ using a glass electrode $\mathrm{pH}$ meter (Model MA 5749 Iskra, Kranj, Slovenia) at $25^{\circ} \mathrm{C}$. The results were expressed as mmols of acid per $100 \mathrm{~g}$.

Reducing, nonreducing and total sugars were quantified by the Luff-Schoorl method, according to Croatian National Regulation (Pravilnik 2000).

Texture was measured using an Instron model 1140 Universal Testing Machine measuring the maximum force $(\mathrm{kg})$ with a standard shear press cell (Model CS1), with a crosshead speed of $20 \mathrm{~cm} / \mathrm{min}$, on $30 \mathrm{~g}$ of vegetable cubes. The data reported are the averages of five determinations. 
Ascorbic acid content (AA) was determined according to Augustin et al (1985). In this method, the total ascorbic acid from the samples was extracted and quantified after titration with 2.6-dichloindophenol.

The mineral content $(\mathrm{Ca}, \mathrm{Na}, \mathrm{K}$ and $\mathrm{P})$ of the celeriac cubes was determined on ash solution after incineration in a furnace at $610 \pm 10^{\circ} \mathrm{C}$. The calcium from ash solution was first precipitated by adding $10 \%(\mathrm{~m} / \mathrm{v}) \mathrm{NH}_{4} \mathrm{Cl}, 5 \%(\mathrm{~m} / \mathrm{v})\left(\mathrm{NH}_{4}\right)_{2} \mathrm{C}_{2} \mathrm{O}_{4} \times \mathrm{H}_{2} 0$ and $10 \%(\mathrm{~m} / \mathrm{v}) \mathrm{NH}_{4} \mathrm{OH}$. The precipitate was then filtered through filter paper and washed out with $10 \%(\mathrm{~m} / \mathrm{v}) \mathrm{H}_{2} \mathrm{SO}_{4}$. Finally, calcium content was determined by titration with $0.1 \mathrm{~N} \mathrm{KMnO}_{4}$, where $1 \mathrm{~mL} \mathrm{KMnO}_{4}$ corresponded to $2.00 \mathrm{mg}$ of $\mathrm{Ca}$. The sodium and potassium analyses were performed by flame atomic emission spectrophotometry and phosphorus was analysed by visible-ultraviolet spectrophotometry using the molybdate colorimetric method at $400 \mathrm{~nm}$ wavelength (AOAC 1991).

Hydroxymethylfurfural (HMF) was quantified by the barbituric acid-toluidine method, proposed by Croatian National Regulation (Pravilnik 2000), in sugar syrups which remained after every set of procedures. A UV/Vis spectrophotometer (Model SP 1700, Unicam, Cambridge, U.K.) was used.

The colour of the samples was determined using a spectrophotocolorimeter (Model DC 3890, DataColor, Lucerne, Switzerland), by the measurement of their reflectance spectra using a D65 light source. The CIE L*a*b* colour co-ordinates (Hunter 1975; Clydesdale 1976) were determined by means of Data Match Software. The colour attributes of hue $\left(a^{*} / b^{*}\right)$ and saturation $\left(a^{* 2}+b^{* 2}\right)^{1 / 2}$ were also expressed.

Changes in the texture due to heating were monitored after pre-treatment while all other physicochemical analyses were conducted on raw celeriac, on celeriac after treatment in boiling water and on celeriac cubes, both after candying and after drying had been carried out. HMF was quantified in the sugar syrups.

\subsection{Sensory evaluation}

Acceptability of the procedures was evaluated by a 5-member consumer panel drawn from the staff of the Faculty of Food Technology and Biotechnology, University of Zagreb, Croatia. Panelists were selected by screening on the basis of having consumed celeriac and being familiar with sensory evaluation methodology and the attributes of candied products. Samples were randomly coded and before sampling, panel members received instructions about the questionnaire. Sensory evaluation was carried out according to the modified method described by Hegedušić et al (1996). The quality attributes of taste, appearance, colour and odour were evaluated using a scoring method with a 20 -point total scale. The maximum points were: taste-8, appearance-6, colour-4 and odour-2.

\subsection{Statistical analysis}

Each experiment had two replications. To determine statistically significant differences between samples $(P<0.05 ; P<0.01)$, analysis of variance and the Duncan multiple range test were performed using a statistical software program (SPSS for Windows Version 7.0). Unless stated otherwise, all significant differences are at $P<0 \cdot 01$.

\section{Results and discussion}

\subsection{Physicochemical analyses}

Heating in boiling water is necessary before candying to soften the cell structure and enable easier sugar syrup migration. Vegetables soften upon heating due to both turgor loss caused 
Table 1. Chemical composition and consistency of raw celeriac and heat-treated celeriac cubes before candying.

Each value represents mean \pm standard error

\begin{tabular}{|c|c|c|}
\hline Analysis & Raw celeriac & Celeriac cubes $^{\mathrm{a}}$ \\
\hline 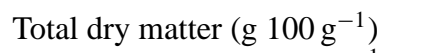 & $12 \cdot 24 \pm 0 \cdot 04$ & $9 \cdot 34 \pm 0 \cdot 07$ \\
\hline Total acidity $\left(\mathrm{mmol} 100 \mathrm{~g}^{-1}\right)$ & $2 \cdot 43 \pm 0.01$ & $0 \cdot 40 \pm 0.01$ \\
\hline $\mathrm{pH}$ & $6 \cdot 66 \pm 0 \cdot 04$ & $7 \cdot 38 \pm 0.03$ \\
\hline Total sugars $\left(\mathrm{g} 100, \mathrm{~g}^{-1}\right)$ & $2 \cdot 70 \pm 0.03$ & $0.50 \pm 0.01$ \\
\hline Reducing sugars $\left(\mathrm{g} 100 \mathrm{~g}^{-1}\right)$ & $0.68 \pm 0.02$ & $0.25 \pm 0.02$ \\
\hline Nonreducing sugars $\left(\mathrm{g} 100 \mathrm{~g}^{-1}\right)$ & $1.92 \pm 0.02$ & $0 \cdot 24 \pm 0 \cdot 01$ \\
\hline Ascorbic acid $\left(\mathrm{mg} 100 \mathrm{~g}^{-1}\right)$ & $6 \cdot 00 \pm 0.08$ & $0.63 \pm 0.02$ \\
\hline 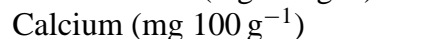 & $73.94 \pm 0.04$ & $56 \cdot 77 \pm 0 \cdot 04$ \\
\hline Sodium (mg $\left.100 \mathrm{~g}^{-1}\right)$ & $33.84 \pm 0.03$ & $17 \cdot 24 \pm 0 \cdot 02$ \\
\hline Potassium $\left(\mathrm{mg}_{\left.100 \mathrm{~g}^{-1}\right)}\right.$ & $308 \cdot 33 \pm 0 \cdot 03$ & $118 \cdot 70 \pm 0 \cdot 04$ \\
\hline Phosphorus (mg $100 \mathrm{~g}^{-1}$ ) & $52 \cdot 01 \pm 0 \cdot 03$ & $33 \cdot 08 \pm 0 \cdot 04$ \\
\hline Consistency $(\mathrm{kg})$ & $40 \cdot 10 \pm 0 \cdot 07$ & $38.30 \pm 0.05$ \\
\hline
\end{tabular}

${ }^{\mathrm{a}}$ Heat-treated celeriac cubes before candying

by cell membrane disruption and the changes in the pectic substances which are involved in holding the cells together (Greve et al 1994; Ryden \& Selvendran 1990). Softening of vegetables is a biphasic process (Ramesh et al 1998). Since there is limited information about softening of celeriac due to heating, changes in the texture after pre-treatment process were monitored.

The consistency of celeriac cubes decreased due to heating (table 1) In our previous study (Krešić et al 2002), we observed that after proposed pre-treatment celeriac tissue softened enough to ensure good sugar syrup penetration. The total acidity value decreased after thermal treatment due to leaching. A loss of dry matter and sugars was also recorded, possibly due to leaching of some soluble compounds into the water. Celeriac cubes before candying had a considerably lower ascorbic acid content than in the raw celeriac because of a very rapid vitamin $\mathrm{C}$ loss during thermal treatment. Ascorbic acid is always lost during thermal treatment (Ilow et al 1995) and therefore, in this study, ascorbic acid was added to the initial sugar syrups in the first cycle of procedures CA and CAD. The mean concentrations of mineral elements were similar to those found in the literature (Kulier 1996; Souci et al 2000) with the exception of a slightly smaller amount of phosphorus. One of the predictable but undesirable changes which occurred during thermal treatment was mineral loss. This is consistent with the data reported by Rodriguez (1993), and Bognar (1998), according to which, mineral loss could be in the range of 25 to $50 \%$.

Chemical composition of candied celeriac is shown in table 2. Procedures proposed in this work ensure products with the required content of dry matter and sugar respectively (Chen 1989). According to some authors (Erba et al 1994; Forni et al 1997; Mohamed et al 1993), changes in chemical composition and colour which occur after air-drying of products with reduced water activity must be taken into consideration. In view of this, we also conducted air-drying procedure and the physicochemical composition of these samples (CD and CAD, respectively) are summarized in table 2 . Owing to sugar syrup migration, candying causes increase in total dry matter, with significantly $(P<0.01)$ higher values after drying. The high total dry matter of the candied product can be attributed to the highly concentrated syrup used 
Table 2. Chemical composition of candied celeriac.

\begin{tabular}{|c|c|c|c|c|c|c|}
\hline Procedure & $\begin{array}{c}\text { Total dry } \\
\text { matter } \\
\left(\mathrm{g} 100 \mathrm{~g}^{-1}\right. \\
\mathrm{FW})\end{array}$ & $\begin{array}{c}\text { Total } \\
\text { acidity } \\
\left(\mathrm{mmol} 100 \mathrm{~g}^{-1}\right. \\
\text { FW })\end{array}$ & $\mathrm{pH}$ & $\begin{array}{l}\text { Total sugars } \\
\left(\mathrm{g} 100 \mathrm{~g}^{-1}\right. \\
\text { FW) }\end{array}$ & $\begin{array}{c}\text { Reducing } \\
\text { sugars } \\
\left(\mathrm{g} 100 \mathrm{~g}^{-1}\right. \\
\mathrm{FW})\end{array}$ & $\begin{array}{l}\text { Nonreducing } \\
\text { sugars } \\
\left(\mathrm{g} 100 \mathrm{~g}^{-1}\right. \\
\text { FW) }\end{array}$ \\
\hline $\mathrm{C} 1$ & $75 \cdot 50^{\mathrm{b}}$ & $8 \cdot 88^{d}$ & $4 \cdot 01^{\mathrm{b}}$ & $72 \cdot 40^{\mathrm{b}}$ & $33 \cdot 72^{\mathrm{d}}$ & $38 \cdot 68^{\mathrm{f}}$ \\
\hline $\mathrm{C} 2$ & $75.46^{\mathrm{b}}$ & $0.60^{\mathrm{e}}$ & $5.74^{\mathrm{a}}$ & $71 \cdot 80^{\mathrm{b}}$ & $4.91^{\mathrm{g}}$ & $66 \cdot 89^{\mathrm{d}}$ \\
\hline $\mathrm{C} 3$ & $75 \cdot 50^{\mathrm{b}}$ & $0.40^{\mathrm{e}}$ & $6.53^{\mathrm{a}}$ & $71 \cdot 10^{\mathrm{b}}$ & $0 \cdot 20^{\mathrm{h}}$ & $70 \cdot 90^{\mathrm{b}}$ \\
\hline CD1 & $77 \cdot 80^{\mathrm{a}}$ & $9 \cdot 60^{c}$ & $3 \cdot 34^{c}$ & $73 \cdot 84^{\mathrm{a}}$ & $34 \cdot 80^{\mathrm{c}}$ & $39 \cdot 04^{\mathrm{f}}$ \\
\hline $\mathrm{CD} 2$ & $77 \cdot 47^{\mathrm{a}}$ & $0.60^{\mathrm{e}}$ & $5.74^{\mathrm{a}}$ & $73 \cdot 50^{\mathrm{a}}$ & $6 \cdot 10^{f}$ & $67 \cdot 40^{\mathrm{c}}$ \\
\hline CD3 & $77 \cdot 41^{\mathrm{a}}$ & $0.40^{\mathrm{e}}$ & $6 \cdot 21^{a}$ & $73 \cdot 65^{\mathrm{a}}$ & $0 \cdot 30^{\mathrm{h}}$ & $73 \cdot 35^{\mathrm{a}}$ \\
\hline CA1 & $75 \cdot 45^{\mathrm{b}}$ & $12 \cdot 80^{\mathrm{b}}$ & $3.69^{c}$ & $72 \cdot 24^{\mathrm{b}}$ & $50 \cdot 70^{\mathrm{b}}$ & $21 \cdot 54^{\mathrm{g}}$ \\
\hline CA2 & $75 \cdot 37^{\mathrm{b}}$ & $0.75^{\mathrm{e}}$ & $5 \cdot 72^{\mathrm{a}}$ & $72 \cdot 31^{\mathrm{b}}$ & $8 \cdot 10^{\mathrm{e}}$ & $64 \cdot 21^{\mathrm{e}}$ \\
\hline CA3 & $75 \cdot 76^{\mathrm{b}}$ & $0.35^{\mathrm{e}}$ & $6 \cdot 96^{\mathrm{a}}$ & $71 \cdot 70^{\mathrm{b}}$ & $0 \cdot 20^{\mathrm{h}}$ & $71 \cdot 50^{\mathrm{b}}$ \\
\hline CAD1 & $77 \cdot 38^{\mathrm{a}}$ & $13.57^{\mathrm{a}}$ & $3 \cdot 14^{\mathrm{c}}$ & $73.92^{\mathrm{a}}$ & $52 \cdot 20^{\mathrm{a}}$ & $21.72^{\mathrm{g}}$ \\
\hline CAD2 & $77 \cdot 41^{\mathrm{a}}$ & $0 \cdot 80^{\mathrm{e}}$ & $5 \cdot 50^{\mathrm{a}}$ & $73.98^{\mathrm{a}}$ & $8 \cdot 80^{\mathrm{e}}$ & $65 \cdot 18^{\mathrm{e}}$ \\
\hline CAD3 & $77 \cdot 32^{\mathrm{a}}$ & $0.40^{\mathrm{e}}$ & $6 \cdot 09^{\mathrm{a}}$ & $73 \cdot 12^{\mathrm{a}}$ & $0 \cdot 30^{\mathrm{h}}$ & $72 \cdot 82^{\mathrm{a}}$ \\
\hline
\end{tabular}

Within each column, mean values are significantly different $(P<0.01)$, if they do not share the same letter (Duncan's multiple range test)

FW - fresh weight

in the procedure and the concentration effect of losing moisture after drying. Drying causes also significant $(P<0.01)$ increase in total sugar content (compare $\mathrm{C} 1: 72.40 \mathrm{~g} / 100 \mathrm{~g} \mathrm{FW}$ with $73.84 \mathrm{~g} / 100 \mathrm{~g} \mathrm{FW}(\mathrm{CD} 1))$. The same significant increase $(P<0.01)$ can be seen in the amount of reducing and non-reducing sugar contents after drying. Total acidity considerably decreases, and $\mathrm{pH}$ increases, through the three cycles, despite the addition of citric acid ( $\mathrm{C} 1$, CD1) or ascorbic and citric acid (CA1, CAD1) in the first cycle. These acids cause sucrose hydrolysis and also help prevent loss of ascorbic acid (Robbers et al 1997). Drying causes significant acidity increase $(P<0.01)$ only in the samples from the first cycle, while in other procedures, no significant acidity changes $(P>0.01)$ are observed. Ascorbic and/or citric acids cause sucrose hydrolysis in the sugar solutions. Sucrose hydrolysis is doubly important: there is an increase in the reducing sugar content of candied celeriac and it also confers good mouth-texture and a pleasant taste to the candied product. The chemical composition of reduced moisture products is influenced by the nature of the sugars in the osmotic solution (Maltini et al 1990). The ratio of reducing to nonreducing sugars is considerably promoted by acids, and consequently the reducing sugar contents are higher in procedure CA1 than in $\mathrm{C} 1$. The opposite effect occurs with nonreducing sugars, whose concentration increase as sucrose hydrolysis slows down.

Results of ascorbic acid and mineral contents in candied samples are shown in table 3. To prevent possible variation due to different dry matter contents of the samples, the concentrations are based on unit dry matter. Sugar syrup enrichment with ascorbic acid causes significant $(P<0.01)$ increase of vitamin $C$ in candied samples, with slightly diminished value after drying. The effect of vitamin enrichment diminishes in the second cycle, while all other samples are not significantly different $(P<0 \cdot 01)$. Candying causes slight decrease in mineral content through three cycles. Drying has no significant influence on mineral composition overall, but causes decrease in the first cycle, the only exception being sodium, whose concentration does not change significantly during the procedure. 
Table 3. Content of ascorbic acid and mineral elements ( $\mathrm{mg} \mathrm{g}^{-1}$ dry weight) in candied celeriac.

\begin{tabular}{|c|c|c|c|c|c|}
\hline Procedure & Ascorbic acid & $\mathrm{Ca}$ & $\mathrm{Na}$ & K & $\mathrm{P}$ \\
\hline $\mathrm{C} 1$ & $0 \cdot 007^{\mathrm{d}}$ & $0.46^{\mathrm{a}}$ & $0 \cdot 04^{\mathrm{b}}$ & $0.65^{\mathrm{a}}$ & $0 \cdot 21^{\mathrm{a}}$ \\
\hline $\mathrm{C} 2$ & $0.008^{\mathrm{d}}$ & $0.21^{\mathrm{c}}$ & $0 \cdot 05^{\mathrm{ab}}$ & $0.47^{\mathrm{c}}$ & $0 \cdot 17^{\mathrm{c}}$ \\
\hline $\mathrm{C} 3$ & $0.008^{\mathrm{d}}$ & $0 \cdot 20^{\mathrm{c}}$ & $0 \cdot 05^{\mathrm{ab}}$ & $0.49^{c}$ & $0 \cdot 17^{\mathrm{c}}$ \\
\hline CD1 & $0.008^{\mathrm{d}}$ & $0.42^{\mathrm{b}}$ & $0 \cdot 04^{\mathrm{b}}$ & $0.61^{\mathrm{b}}$ & $0 \cdot 19^{b}$ \\
\hline $\mathrm{CD} 2$ & $0.008^{\mathrm{d}}$ & $0.19^{c}$ & $0.04^{\mathrm{b}}$ & $0.46^{\mathrm{c}}$ & $0.17^{\mathrm{c}}$ \\
\hline CD3 & $0.008^{\mathrm{d}}$ & $0 \cdot 18^{\mathrm{c}}$ & $0 \cdot 04^{\mathrm{b}}$ & $0.48^{\mathrm{c}}$ & $0 \cdot 16^{\mathrm{c}}$ \\
\hline CA1 & $7.72^{\mathrm{a}}$ & $0.49^{\mathrm{a}}$ & $0.04^{\mathrm{b}}$ & $0.69^{\mathrm{a}}$ & $0.20^{\mathrm{a}}$ \\
\hline $\mathrm{CA} 2$ & $0 \cdot 26^{\mathrm{c}}$ & $0.24^{c}$ & $0 \cdot 04^{\mathrm{b}}$ & $0.51^{\mathrm{c}}$ & $0 \cdot 17^{\mathrm{c}}$ \\
\hline CA3 & $0.007^{\mathrm{d}}$ & $0 \cdot 22^{\mathrm{c}}$ & $0 \cdot 04^{\mathrm{b}}$ & $0.51^{\mathrm{c}}$ & $0 \cdot 17^{\mathrm{c}}$ \\
\hline CAD1 & $7 \cdot 62^{\mathrm{b}}$ & $0 \cdot 40^{\mathrm{b}}$ & $0 \cdot 04^{\mathrm{b}}$ & $0 \cdot 60^{\mathrm{b}}$ & $0 \cdot 18^{\mathrm{b}}$ \\
\hline CAD2 & $0.29^{c}$ & $0.21^{\mathrm{c}}$ & $0 \cdot 04^{\mathrm{b}}$ & $0.50^{c}$ & $0 \cdot 16^{\mathrm{c}}$ \\
\hline CAD3 & $0.007^{\mathrm{d}}$ & $0.21^{\mathrm{c}}$ & $0.04^{\mathrm{b}}$ & $0.50^{c}$ & $0.16^{\mathrm{c}}$ \\
\hline
\end{tabular}

Within the same column mean values are significantly different $(P<0 \cdot 01)$, if they do not share the same letter (Duncan's multiple range test)

Colour data for lightness $\left(L^{*}\right)$, hue and saturation are shown in table 4. Heat treatments affect almost all pigments in vegetables (Archana et al 1995). In the present study, treatment in boiling water caused significant $(P<0 \cdot 01)$ decrease in lightness and hue, which indicates a greater amount of the yellow pigment. Candied celeriac cubes from all procedures are generally darker after candying, with more yellow component (b, data not reported), but with lower hue values and less saturated colour. Lightness significantly $(P<0 \cdot 01)$ increases

Table 4. Colour attributes of candied celeriac.

\begin{tabular}{lccc}
\hline Sample & $L^{*}$ & Saturation & Hue \\
\hline Raw celeriac & $83 \cdot 17^{\mathrm{a}}$ & $9 \cdot 77^{\mathrm{h}}$ & $101 \cdot 90^{\mathrm{a}}$ \\
Celeriac before candying & $70 \cdot 86^{\mathrm{b}}$ & $16 \cdot 01^{\mathrm{b}}$ & $99 \cdot 29^{\mathrm{b}}$ \\
Celeriac after candying & & & \\
C1 & $62 \cdot 35^{\mathrm{f}}$ & $14 \cdot 98^{\mathrm{c}}$ & $92 \cdot 71^{\mathrm{h}}$ \\
C2 & $66 \cdot 54^{\mathrm{c}}$ & $13 \cdot 88^{\mathrm{d}}$ & $98 \cdot 64^{\mathrm{d}}$ \\
C3 & $67 \cdot 66^{\mathrm{b}}$ & $13 \cdot 78^{\mathrm{e}}$ & $98 \cdot 81^{\mathrm{c}}$ \\
CD1 & $61 \cdot 64^{\mathrm{g}}$ & $19 \cdot 67^{\mathrm{a}}$ & $90 \cdot 13^{\mathrm{i}}$ \\
CD2 & $65 \cdot 45^{\mathrm{d}}$ & $14 \cdot 97^{\mathrm{c}}$ & $93 \cdot 03^{\mathrm{g}}$ \\
CD3 & $66 \cdot 40^{\mathrm{c}}$ & $14 \cdot 02^{\mathrm{d}}$ & $98 \cdot 76^{\mathrm{cd}}$ \\
CA1 & $65 \cdot 81^{\mathrm{d}}$ & $12 \cdot 91^{\mathrm{f}}$ & $96 \cdot 32^{\mathrm{f}}$ \\
CA2 & $66 \cdot 59^{\mathrm{c}}$ & $11 \cdot 79^{\mathrm{g}}$ & $97 \cdot 80^{\mathrm{de}}$ \\
CA3 & $70 \cdot 22^{\mathrm{b}}$ & $10 \cdot 41^{\mathrm{h}}$ & $99 \cdot 97^{\mathrm{b}}$ \\
CAD1 & $65 \cdot 21^{\mathrm{e}}$ & $16 \cdot 88^{\mathrm{b}}$ & $93 \cdot 17^{\mathrm{g}}$ \\
CAD2 & $66 \cdot 10^{\mathrm{d}}$ & $14 \cdot 86^{\mathrm{c}}$ & $97 \cdot 43^{\mathrm{e}}$ \\
CAD3 & $68 \cdot 83^{\mathrm{bc}}$ & $12 \cdot 26^{\mathrm{f}}$ & $99 \cdot 13^{\mathrm{bc}}$ \\
\hline
\end{tabular}

Means in columns with different letters are significantly different $(P<0 \cdot 01)$ according to Duncan's multiple range test 


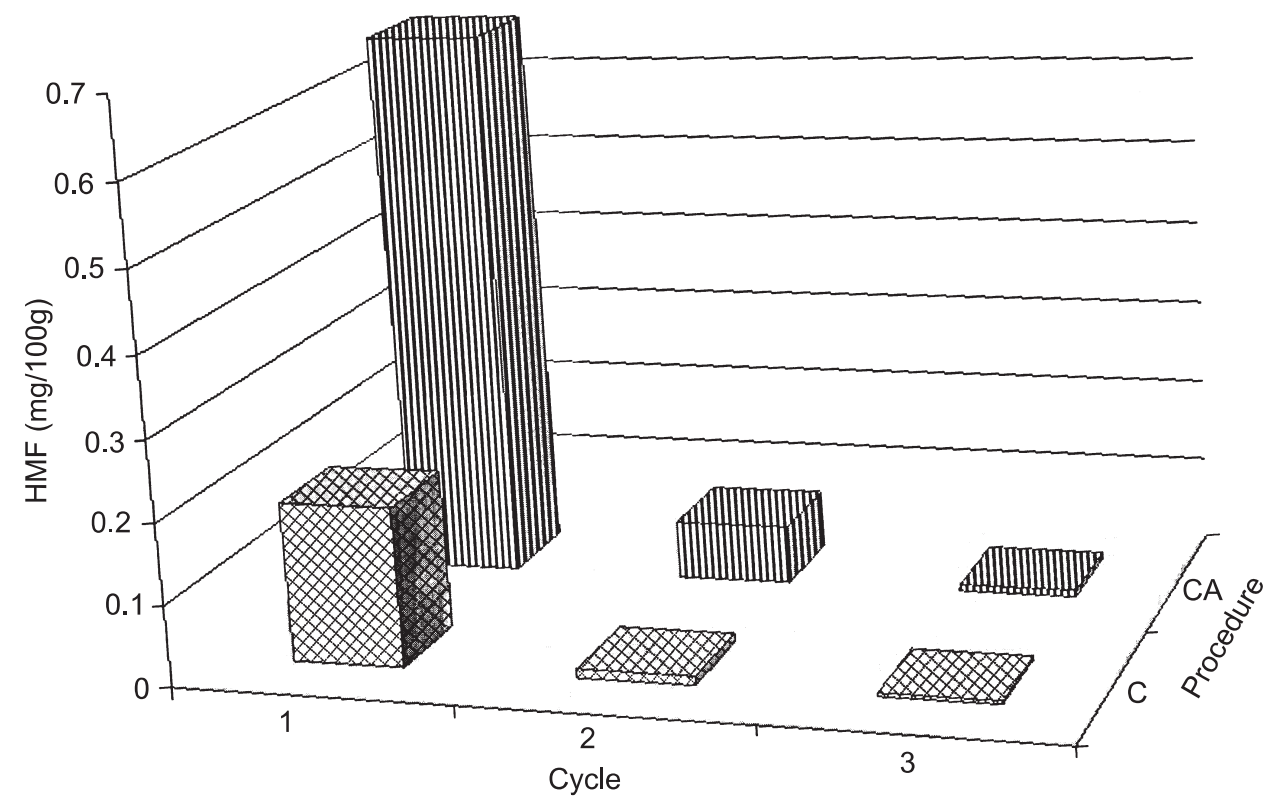

Figure 1. Concentration of hydroxymethylfurfural in sugar syrups leftover after procedures $C$ (cross-hatched bars) and CA (vertically striped bars).

during three cycles in all procedures. Since $L^{*}$ is a measure of the colour on the light-dark axis (Hunter 1975), the rising value indicates that the samples turn lighter. Samples from procedure $\mathrm{CA}$ are in general slightly lighter than those from procedure $\mathrm{C}$, and the same tendency can be observed through the three cycles. This could have been due to the antibrowning action of ascorbic acid. Drying causes significant $(P<0.01)$ darkening of all samples. Non-enyzmic browning, due to both condensation of reducing sugars with amino acids and to pigment conversion, is responsible for most of the darkening occurring during drying (McBean et al 1971). In relation to the saturation data, a slight increase after drying is observed. From the data reported for hue along with lightness it may be concluded that drying leads to a deeper yellow colour.

The results of hydroxymethylfurfural (HMF) concentration measurements in the sugar solutions after candying are shown in figure 1 . The hypothesis to be tested is whether browning of the sugar syrup could be a limitation for its re-use. HMF is one of the most widely used indices in non-enzymatic browning studies. There is a large body of work showing that temperature, duration of heat treatment and sugar composition influence HMF formation (Nagy et al 1990; Garza et al 1999). In our study, the temperature in the candying pilot unit is constant during all procedures, so sugar composition affects HMF formation. The data in figure 1 indicate that HMF tends to decrease in value as the concentration of reducing sugars in the solution decrease, because of sucrose hydrolysis slowing down through the cycles. For the same reason, HMF concentration is higher in solutions CA than in $\mathrm{C}(P<0 \cdot 01)$. There are no significant differences $(P<0 \cdot 01)$ in HMF concentration between solutions from procedures CA3 and $\mathrm{C} 3$ because of slight difference in reducing sugars amount. To support these statements, the content of reducing and non reducing sugars in the solutions were also determined (figure 2). The amount of reducing sugars in solutions C3 and CA3 were 0.3 and $0.4 \mathrm{~g} / 100 \mathrm{~g}$ fresh weight respectively. As previously reported by Garza et al (1999), the reducing sugars, mainly glu- 


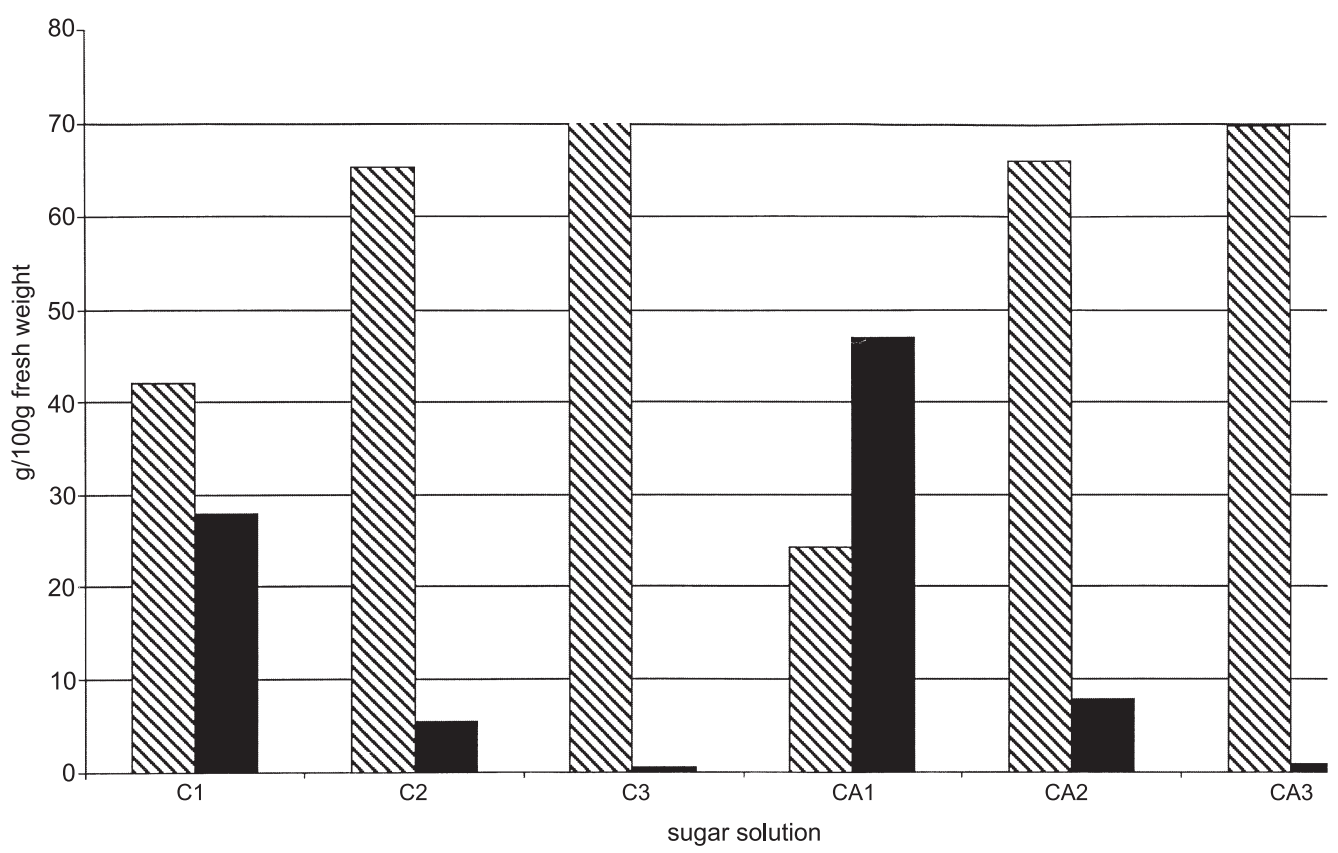

Figure 2. Content of non reducing (hatched bars) and reducing sugars (filled bars) in solutions after candying.

cose and fructose, participate directly in the non-enzymatic browning reactions. Some disaccharides, such as sucrose, can also hydrolyse during thermal treatment, leading to glucose and fructose formation, and owing to diminishing the HMF concentration through three cycles, it could be concluded that the extend of browning is no limitation for the re-use of sugar syrups.

\subsection{Sensory evaluation}

The organoleptic scores for attributes of the candied celeriac are presented in table 5. The sample from procedure CA1 recorded the highest total score for the quality attributes, meaning it qualified as the best method. There is preference for the taste of the products from the first cycle of each procedure, which panelists described as "not too sweet but little bit sourish". Panelists indicated that all the products can be used as commercial confectionery snacks. Scores for odour were not significantly different $(P>0.01)$ between the procedures. As lightness of samples increased through three cycles, this decreased the panelists' assessment for colour. Concerning the colour changes during drying, it is evident that panelists judged darker samples with higher scores for colour but these differences were not significant $(P>$ $0 \cdot 01$ ).

The two-way analysis of variance (ANOVA) was performed to estimate the contribution of different procedures and panelists on sensory evaluation. Results are summarized in table 6 . Analysis of variance shows that the effect of candying procedures is significant $(P<0.01 ; P<0.05)$ for all sensory attributes except odour. Significant variations $(P<0.01)$ among panelists on the assessment of taste and appearance was observed. 
Table 5. Mean organoleptic scores for quality attributes of candied celeriac.

\begin{tabular}{lcccc}
\hline Procedure & Taste $^{1}$ & Appearance $^{1}$ & Colour $^{1}$ & Odour $^{1}$ \\
\hline C1 & $7 \cdot 6^{\mathrm{a}}$ & $5 \cdot 2^{\mathrm{a}}$ & $3 \cdot 6^{\mathrm{a}}$ & $1 \cdot 4^{\mathrm{a}}$ \\
C2 & $5 \cdot 8^{\mathrm{b}}$ & $5 \cdot 1^{\mathrm{a}}$ & $3 \cdot 4^{\mathrm{b}}$ & $1 \cdot 0^{\mathrm{a}}$ \\
C3 & $5 \cdot 6^{\mathrm{b}}$ & $5 \cdot 1^{\mathrm{a}}$ & $2 \cdot 4^{\mathrm{c}}$ & $1 \cdot 6^{\mathrm{a}}$ \\
CD1 & $7 \cdot 5^{\mathrm{a}}$ & $4 \cdot 6^{\mathrm{b}}$ & $3 \cdot 8^{\mathrm{a}}$ & $1 \cdot 2^{\mathrm{a}}$ \\
CD2 & $5 \cdot 6^{\mathrm{b}}$ & $4 \cdot 5^{\mathrm{b}}$ & $3 \cdot 5^{\mathrm{b}}$ & $1 \cdot 0^{\mathrm{a}}$ \\
CD3 & $5 \cdot 2^{\mathrm{b}}$ & $4 \cdot 5^{\mathrm{b}}$ & $2 \cdot 6^{\mathrm{c}}$ & $1 \cdot 2^{\mathrm{a}}$ \\
CA1 & $8 \cdot 0^{\mathrm{a}}$ & $5 \cdot 2^{\mathrm{a}}$ & $3 \cdot 9^{\mathrm{a}}$ & $1 \cdot 8^{\mathrm{a}}$ \\
CA2 & $5 \cdot 4^{\mathrm{b}}$ & $5 \cdot 2^{\mathrm{a}}$ & $3 \cdot 2^{\mathrm{b}}$ & $1 \cdot 6^{\mathrm{a}}$ \\
CA3 & $5 \cdot 6^{\mathrm{b}}$ & $5 \cdot 0^{\mathrm{a}}$ & $2 \cdot 2^{\mathrm{c}}$ & $1 \cdot 4^{\mathrm{a}}$ \\
CAD1 & $7 \cdot 6^{\mathrm{a}}$ & $4 \cdot 8^{\mathrm{b}}$ & $4 \cdot 0^{\mathrm{a}}$ & $1 \cdot 2^{\mathrm{a}}$ \\
CAD2 & $5 \cdot 6^{\mathrm{b}}$ & $4 \cdot 8^{\mathrm{b}}$ & $3 \cdot 4^{\mathrm{b}}$ & $1 \cdot 2^{\mathrm{a}}$ \\
CAD3 & $5 \cdot 8^{\mathrm{b}}$ & $4 \cdot 7^{\mathrm{b}}$ & $2 \cdot 4^{\mathrm{c}}$ & $1 \cdot 4^{\mathrm{a}}$ \\
\hline
\end{tabular}

Any means in the same column with the same letters are not significantly different $(P<$ 0.01) (Duncan's multiple range test)

${ }^{1}$ Means based on 20-point scale (maximum points: taste $=8$; appearance $=6$; colour $=$ 4 ; odour $=2$ )

\section{Conclusions}

All the procedures proposed in this work would ensure candied celeriac with acceptable quality for this type of product. Although no differences in total sugar contents between candied samples were established, differences in sugar composition occurred. The main differences occurred in reducing to nonreducing sugar ratio because of ascorbic acid addition. Initial sugar syrup enrichment with $1 \%(\mathrm{~m} / \mathrm{v})$ ascorbic acid in the first cycle (procedure CA1) resulted in a product adjudged with the highest total score for quality attributes. Addition of ascorbic acid protected the natural colour, improved texture and exibited antibrowing effect. Panelists indicated that the taste of these sample was less sweet and a little sour, thus having the most positive organoleptic effect. Drying $\left(60^{\circ} \mathrm{C}, 8 \mathrm{~h}\right)$ caused significant $(P<0.01)$ increase in total dry matter and total sugars respectively. As confirmed by the colour coordinates, through three cycles, samples turned lighter while drying caused darkening in all procedures. The

Table 6. Analysis of variance of organoleptic attribute scores for candied celeriac.

\begin{tabular}{|c|c|c|c|c|c|c|c|c|c|}
\hline \multirow{3}{*}{$\begin{array}{l}\text { Source of } \\
\text { variation }\end{array}$} & \multirow{3}{*}{$d f$} & \multicolumn{8}{|c|}{ Sensory attribute } \\
\hline & & \multicolumn{2}{|c|}{ Taste } & \multicolumn{2}{|c|}{ Appearance } & \multicolumn{2}{|c|}{ Colour } & \multicolumn{2}{|c|}{ Odour } \\
\hline & & $\mathrm{ms}$ & $\mathrm{F}$ & $\mathrm{ms}$ & $\mathrm{F}$ & $\mathrm{ms}$ & $\mathrm{F}$ & $\mathrm{ms}$ & $\mathrm{F}$ \\
\hline Procedure & 11 & $4 \cdot 13$ & $7 \cdot 06^{* *}$ & 0.66 & $2 \cdot 29^{*}$ & $1 \cdot 91$ & $6 \cdot 57^{* *}$ & $0 \cdot 30$ & $1 \cdot 32^{\mathrm{ns}}$ \\
\hline Panelists & 4 & $2 \cdot 28$ & $3.90^{* *}$ & $2 \cdot 23$ & $7.76^{* *}$ & 0.71 & $2 \cdot 44^{\mathrm{ns}}$ & $0 \cdot 14$ & $0.63^{\text {ns }}$ \\
\hline Error/within cells & 44 & 0.58 & & 0.29 & & $0 \cdot 29$ & & 0.22 & \\
\hline
\end{tabular}

Key: ms mean square; $F$ Fisher ratio; ${ }^{\text {ns }}$ not significant; ${ }^{* *}$ significant at $P<0 \cdot 01 ;{ }^{*}$ significant at $P<0.05$ 
described re-use of sugar syrup did not cause sugar syrup deterioration and this was confirmed with decreased HMF concentration.

The products developed are free from preservatives, maintain the attractive colour and have an agreeable texture what makes them suitable for different applications as an ingredient. Beside the potential use as a snack, at this moment in our laboratory further research is in progress with the aim to produce value-added dairy products by addition of the candied celeriac cubes.

\section{References}

AOAC 1980 Official methods of analysis 13th edn (Washington, DC: Association of Official Analytical Chemists) No 46. 024-22.061-22018

AOAC 1991 Official methods of analysis 15th edn (Arlington, VA: Association of Official Analytical Chemists) 2nd suppl. 99.25. pp 101-102

Archana G N, Prakash J, Asha M R, Chand N 1995 Effects of processing on pigments of certain selected vegetables. J. Food Quality 18: 91-101

Augustin J, Klein B P, Becker D, Venston P B 1985 Methods of vitamin assay 4th edn (Chichester, UK: Wiley) pp 334-336

Ballerini-Goffe M 1992 Process for obtaining new candied, industrially produced agricultural food products. European Patent Application, EP 0483012

Bognar A 1998 Comparative study of frying to other cooking techniques influence on the nutritive value. Grasas Aceites 49: 250-260

Chen A O 1989 Quality improvement of candied fruits. ACS Symp. Ser.-Am. Chem. Soc. 405: 319-325

Clydesdale F M 1976 Instrumental techniques for colour measurements of food. Food Technol. 30: $52-59$

Crozier A, Lean M E J, McDonald M S, Black C 1997 Quantitative analysis of the flavonoid content of commercial tomatoes, onions, lettuce and celery. J. Agric. Food Chem. 45: 590-595

Desrosier N W, Desrosier J 1977 The technology of food preservation (Westport, CT: AVI Publishing) pp 341-345

Enze P 1994 Method for manufacture candied fruits and vegetables. Chinese Patent Application CN 1080124

Erba M L, Forni E, Colonello A, Gianciacomo R 1994 Influence of sugar composition and dehydration levels on the chemical-physical characteristics of osmodehydrofrozen fruit. Food Chem. 50: 69-73

Forni E, Sormani A, Scalise S, Torreggiani D 1997 The influence of sugar composition on the colour stability of osmodehydrofrozen intermediate moisture apricots. Food Res. Int. 30: 87-94

Garza S, Ibarz A, Págan J, Giner J 1999 Non-enzymatic browning in peach puree during heating. Food Res. Int. 32: 335-343

Giangiacomo R, Torreggiani D, Abbo E 1987 Osmotic dehydration of fruit: Sugars exchange between fruit and extracting syrups. J. Food Process. Preserv. 11: 183-195

Greve L C, Shackel K A, Ahmadi H, McArdle R N, Gohlke J R, Labavitch J M 1994 Impact of heating on carrot firmness: contribution of cellular turgor. J. Agric. Food Chem. 42: 2896-2899

Hegedušić V, Herceg Z, Rexhepi A 1996 Processing and storage effects on the quality of dehydrated apples. Acta Aliment. 25: 151-161

Hermann K 1996 Inhalsstoffe von Sellerie. Ind. Obst. Gemüs. 81: 223-227

Hertog M GK, Hollman P C H, Venema D P 1992 Optimization of a quantitative HPLC determination of potentially anticarcinogenic flavonoids in vegetables and fruits. J. Agric. Food Chem. 40: 15911598

Hicks K B, Haines R M, Tong C B S, Sapers G M, El-Atawy Y, Irwin P L, Seib P A 1996 Inhibition of enzymatic browning in fresh fruit and vegetable juices by soluble and insoluble forms of betacyclodextrin alone or in combination with phosphates. J. Agric. Food Chem. 44: 2591-2594 
Hunter R S 1975 Scales for the measurements of colour differences. In: The measurements of appearance (edn) R S Hunter (New York: John Wiley \& Sons) pp 133-140

Ilow R, Regulska-Ilow B, Szymczak J, 1995 Assesment of vitamin C losses in conventionally cooked and micro-wave processed vegetables. Bromatol. Chem. Toksykol. 28: 317-321

Kowalska H, Lenart A 2001 Mass exchange during osmotic pretreatment of vegetables. J. Food Eng. 49: 137-140

Krešić G, Lelas V, Šimundić B 2002 The effect of pre-treatment duration on the chemical composition of candied celeriac. First Central European Congress of Food and Nutrition (Book of Abstracts) p. 187

Maltini E, Torreggianni D, Forni E, Lattuada R 1990 Osmotic properties of fruit juice concentrates. In Engineering and food, physical properties and process control (eds) W L Spiess, H Schubert (London: Elsevier Science) pp 567-573

McBean D McG, Joslyn M A, Nury F S 1971 The biochemistry of fruit and their products (ed.) A C Ulme (London: Academic Press) pp. 627-629

Mohamed S, Kyi K M M, Sharif Z M 1993 Protective effect of cysteine-HCl on vitamin C in dehydrated pickled/candied pineapples and guava. J. Sci. Food Agric. 61: 133-136

Nagy S, Lee H, Rouseff R L, Lin J C C 1990 Nonenzymatic browning of commercially canned and bottled grapefruit juice. J. Agric. Food Chem. 38: 343-346

Nicholl P, Predergast M 1998 Disinfection of shredded salad ingredients with sodium dichloroisocyanurate. J. Food Process. Preserv. 22: 67-69

Pravilnik 2000 Pravilnik o kakvoći meda i pčelinjih proizvoda (Regulations about honey and honey products quality) Official Gazette No. 20, Zagreb: Croatian Ministry of Agriculture and Forestry., pp. 651

Rahman M S, Sablani S S, Al-Ibrahim M A 2001 Osmotic dehydration of potato: Equilibrium kinetics. Dry. Technol. 19: 1163-1176

Ramesh M N, Sathyanarayana K, Girish A B 1998 Biphasic model for the kinetics of vegetables cooking at $100^{\circ}$ C. J. Food Eng. 35: 127-133

Rastogi N K, Niranjan K 1998 Enhanced mass transfer during osmotic dehydration of high pressure treated pineapple. J. Food Sci. 63: 508-511

Robbers M, Singh R P, Cunha L M 1997 Osmotic-convective dehydrofreezing process for drying kiwi fruit. J. Food Sci. 62: 1039-1042

Rodriguez T 1993 Mineral losses in hot water blanched and microwave-blannched green dry white beans. J. Agric. Univ. Puerto Rico 77: 129-135

Ryden P, Selvendran R R 1990 Cell-wall polysaccharides and glycoproteins of parenchymatous tissue of runner bean. Biochem. J. 269: 393-402

Souci S W, Fachmann W, Kraut H 2000 Food composition and nutrition tables 6th edn. (eds) Deutsche Forschungsanstalt für Lebensmittelchemie, Garching b. München, Medpharm Scientific Publishing, Stuttgart, Germany (Boca Raton, London, New York, Washington, DC: CRC Press) pp 681-682

Kulier I (ed.) 1996 Standard Euro-food composition tables (Zagreb: Croatian Farmer) pp 43-44

Thomann R J, Ehrich J, Bauermann U 1993 Distillation and use of essential oils from dill, celery, lovage and parsley, made in Germany. Acta Hortic. 333: 101-111

Torres M D A, Canet W 2001 Rheological properties of frozen vegetable purees. Effect of freeze-thaw cycles on thawing conditions. Eur. Food Res. Technol. 213: 30-37

Tsi D, Tan B K 2000 The mechanism underlying the hypocholesterolaemic activity of aqueous celery extract, its butanol and aqueous fraction in genetically hypercholesterolaemic rats. Life Sci. 66: 755767 